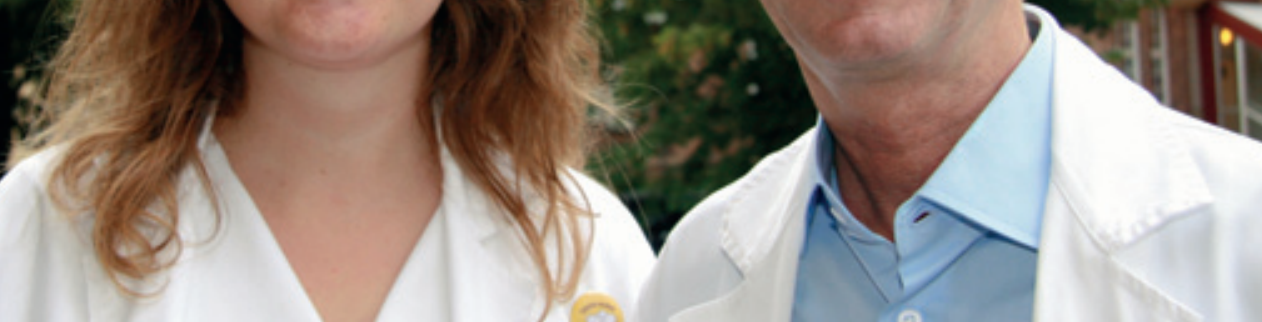

Anne-Marie Aas og Kåre I. Birkeland. Foto Birgit Skjelvik, Medieavdelingen, Oslo universitetssykehus, Aker

\section{Leptin forbundet med vektøkning ved diabetes}

\author{
Insulinbehandling gir økt nivå av leptin. Det kan forklare hvorfor insulin- \\ behandling ved type 2-diabetes ofte gir vektøkning.
}

Insulin og leptin er to sentrale hormoner som deltar i regulering av kroppsvekten hos mennesker. Oppstart av insulinbehandling ved type 2-diabetes fører ofte til vektøkning. Mekanismene for dette er bare delvis kjent. I en ny undersøkelse har norske forskere funnet en mulig sammenheng mellom insulinindusert leptinøkning og påfølgende vektøkning ved insulinbehandling av pasienter med type 2-diabetes (1).

- Vi observerte at leptinnivået i serum økte etter 3-4 timers infusjon av insulin hos pasienter med type 2-diabetes som skulle begynne med insulinbehandling. Etter at de var behandlet med insulin i ett år, hadde vekten i gjennomsnitt økt med $6 \%$, mens fastende leptinnivå var økt med $108 \%$. Det overraskende var at det var en sterk korrelasjon mellom den leptinøkning som ble observert under insulininfusjon før insulinbehandlingen startet, og den vektøkning som ble observert det første året insulinbehandlingen pågikk, sier professor Kåre I. Birkeland ved Oslo universitetssykehus, Aker.

- I en annen studie målte vi nivået av fastende serumleptin hver tredje måned hos pasienter som startet insulinbehandling. Det var en markant økning i leptinnivået allerede etter tre måneder, mens pasientenes vekt økte først etter seks måneder. Det var en signifikant korrelasjon mellom leptinøkningen fra 0 til 3 måneder og økningen i fettmasse fra 0 til 12 måneder.

En mulighet er at insulin stimulerer leptinproduksjonen og at de økte leptinnivåene fører til leptinresistens i hypothalamus som reduserer den normale appetitthemmende effekten av leptin.

Hvorvidt leptinresistens virkelig eksis- terer som viktig klinisk fenomen, er omdiskutert. Leptinmangel hos mennesker er svært sjeldent, men er forbundet med svær overvekt og leptinbehandling gir dramatisk vektreduksjon. De fleste overvektige har derimot svært høye leptinverdier, og mange har spekulert på om en av årsakene er at de er blitt resistente mot leptinets appetitthemmende effekt, sier Birkeland.

\section{Forskning på type 2-diabetes}

Arbeidet utgår fra forskergruppen for type 2-diabetes ved Oslo universitetssykehus, Aker, som ledes av professor Kåre I. Birkeland. Gruppen består av 8-10 ph.d.-kandidater og 3-4 forskere og postdoktorer. De arbeider med problemstillinger knyttet til årsaker, utvikling, forebygging og behandling av type 2-diabetes. Forfatterne av artikkelen er Anne-Marie Aas, Kristian F. Hanssen, Jens Petter Berg, Per M. Thorsby og Kåre I. Birkeland.

\section{Erlend Hem}

erlend.hem@medisin.uio.no

Tidsskriftet

\section{Litteratur}

1. Aas AM, Hanssen KF, Berg JP et al. Insulin-stimulated increase in serum leptin levels precedes and correlates with weight gain during insulin therapy in type 2 diabetes. J Clin Endocrinol Metab 2009; 94: $2900-6$.

\section{Ordforklaringer}

Leptin er det mest sentrale fedmehormonet vi kjenner. Det ble isolert i 1994, produseres i fettvevet og deltar i appetittreguleringen. Leptin er trolig det viktigste enkeltstående bidrag til det kroppsvektregulerende systemet (1).

Diabetes mellitus er en gruppe tilstander med ulike årsaksforhold som karakteriseres ved høy konsentrasjon av glukose i blodet som følge av sviktende insulinsekresjon eller insulinvirkning, eller en kombinasjon av disse to mekanismene. Nedsatt insulinfølsomhet i kombinasjon med redusert insulinsekresjon er kjennetegnet ved type 2-diabetes, som er mest utbredt. Sannsynligvis har ca. 90 000-120000 mennesker diagnostisert diabetes i Norge. Nesten like mange kan tenkes å ha uoppdaget diabetes (2)

\section{Litteratur}

1. Valeur J. Sult og metthet - en biologisk forklaringsmodell. Tidsskr Nor Lægeforen 2007; 127: $2546-8$.

2. Stene LC, Midthjell $K$, Jenum AL et al. Hvor mange har diabetes mellitus i Norge? Tidsskr Nor Lægeforen 2004; 124: 1511-4.

Artikkelen ble publisert i augustutgaven 2009 av Journal of Clinical Endocrinology and Metabolism (http://jcem.endojournals.org), som er det høyest rangerte tidsskriftet innen klinisk endokrinologi

\section{Tips oss}

Er du iferd med å publisere eller har du nylig publisert i et internasjonalt tidsskrift? erlend.hem@medisin.uio.no 